\title{
God-Justice versus Evil in Qoheleth: A Materialist Interpretation
}

\author{
Luke Emeka Ugwueye (PhD)
}

Department of Religion \& Human Relations, Faculty of Arts Nnamdi Azikiwe University, Awka, Anambra State, Nigeria

Email: Lukeemeka@yahoo.com

\section{Doi:10.5901/mjss.2014.v5n8p528}

\begin{abstract}
The aim of the paper is to survey the issue of God-justice versus evil in selected passages of Qoheleth (Ecclesiastes) with slant on the materialist stance. God -justice versus evil is linked with the way justice operates here in the world. The justice of God cannot be separated from the actual experience of justice in the social process, because Yahweh's presence in Israel is known through and against the social process. The well-being of the oppressors in Nigeria is not caused directly by God as though by edict, but their well-being takes place through the nexus of socio-political processes. Likewise the suffering of the poor is not caused by God's hatred but by flawed and narcissistic handling of the system. By and large it is man that causes injustice and it is man that suffers it. Everyone has a part in creating and sustaining a healthier environment for justice, for God of Qoheleth is in our world of flesh and blood to call for justice through the actions of men instead of engaging in the usual reconciliation of God's justice with evil alone. The method of the study is hermeneutical.
\end{abstract}

Keywords: God-justice, evil, Qoheleth, materialist and interpretation

\section{Introduction}

The world in which we live no doubt bears the stamp of misery, sufferings and evil in all its forms. No one here on earth escapes the crippling effect of misery, suffering and evil as all are, at least, subject to death and class distinction or division become meaningless in the face of the prospect of dying. Anxiety reigns day and night, even sleep sometimes is turned into an occasion for further consternation when imagined harm exceeds the horrors of actual reality. Most regrettably, innocent people including children are also exposed to suffering, not only inculpably but without even the possible defence of fleeing from it.

Reflection upon such human situations as above has occupied the minds of thinkers and researchers since time immemorial. They have all in different ways tried to explain the existence of misery, suffering and evil in God's created orderly and harmonious world. These explanations are done while maintaining that God is just, even sometimes at the expense of the "truth". The technical term for this academic enterprise is known as theodicy (God-Justice versus evil).

Theodicy is a philosophico-theological term, which means the justification of the divine providence by the attempt to reconcile the existence of evil with the goodness and sovereignty of God (Stephenson, Voorhees \& Morris, 2004). It is the vindication of the justice and goodness of God in spite of the existence of evil in the world. Hicks (1985) traces the origin of the word to the Greek words theos (God) and dike (justice). It is a kind of technical shorthand for the defence of the justice and righteousness of God in face of the fact of evil. The invention of the word in its French form - theodicee- is commonly and credibly attributed to Von Leibniz. Schuuman (1996) defines theodicy broadly to mean "any interpretation of evil and human existence which enables people to find meaning and purpose in life in spite of the presence of evil in the world" (p.816)

The issue of theodicy in the Old Testament, especially the wisdom books where Qoheleth belongs, has been on speculative levels; thereby ignoring the actual evils experienced in our world, hence the need for this study which offers a materialist reading of three Qoheleth passages. Materialist reading refers to a study or analysis or understanding of text with interest exclusively or chiefly in the material necessities and comfort of the society. It refers to an appraisal of a text or passage with an interest in the socio-political aspect of the meaning. Theodicy concerns justice and most often in handling the subject the justice of God is emphasized more than the justice and injustice here on earth.

In fact justice is a social question about social power and social access, about agreed upon systems and practices of social production, distribution, possession and consumption. The justice of God cannot be separated from the actual experience of justice in the social process, because Yahweh's presence in Israel is known through and against the social process. The justice question in the eight century prophetic era clearly concern social goods; social power, social access, 
and the way they are configured in the society. According to Stuhlmueller (1977), "in the post-exilic age, preaching no longer strove primarily to instill personal goodness and social justice; its goal was the careful functioning of the liturgy" ( $p$. 341). In the eight century prophetic era from where we derive the impetus for this study this was not so for the prophets braved the wrath of the priests and kings to hurl judgment upon the nation and its leadership. The issue centered on practical justice as the standard of behaviour and the measure of covenant operation in Israelite cultic community.

\section{Qoheleth Passages: $3: 16 ; 4: 1$ and 5:8}

Qoheleth like the eight century prophets is very much concerned with the problem of injustice in human affairs. In 3:16, it is stated that in place of "justice there was wickedness and in the place of righteousness even there was wickedness". The oppressors and perpetrators of injustice referred to above are men placed in authority and most always they claim that Yahweh legitimates their unjust deeds. The assumption of order ordained by Yahweh in society may permit oppression and injustice to flourish unrecognized and unchallenged, for it enables rulers to justify their position and policies just as it secures a place in the overall scheme of things for those who are oppressed. Each group, the oppressor and the oppressed, rushed to God's defense where its interests were concerned.

In another passage (4:1), Qoheleth deeply feels the pain of social violence and oppression when he says again "I saw all the oppressions that are practised under the sun. And behold the tears of the oppressed. On the side of their oppressors there was power, and there was no one to comfort them" The overriding issue in the text is that of social power. Any discussion of God's justice must be a critique of the social agency through which that justice is made concrete. Theodicy in Israel, during the eight century prophetic era and in short before the exilic time, was not an esoteric speculation about God, not a supernaturalism, but concerns the handling of power through human agency which claims religious legitimacy. What had been taken as divinely ordered is at least in part seen to be socially and historically

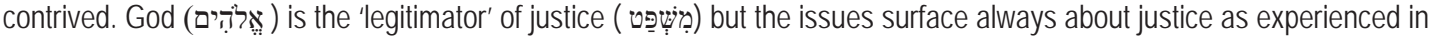
the human sphere.

Qoheleth in his third passage $(5: 8)$ observed that it is the structure of the state with its constant supervision that makes injustice possible. "If you see in a province the poor oppressed and justice and right violently taken away, do not be amazed by a higher one, and there are yet higher ones over them". According to Murphy (1977) the reason one should not be shocked at oppression and pervasion of justice is the structure of the state, in which constant selfish supervision is the predominant feature. The ways of administering social power are here criticized.

Israel's critical theological tradition since the Exodus is precisely a protest about and enquiry into the benefit systems of society in which God is affirmed to be present as dispenser, legitimator and guarantor. As soon as the fact of social evil is acknowledged as above, it becomes clear that theodicy is an enquiry into such arrangements that give excessive life to some at the expense of others in the same cultic community. It is an important fact of the sociology of our scholarship that the enormous concern of Israel for social power and social goods is characteristically bracketed out when we come to the question of theodicy.

This way of understanding theodicy is an overriding concern for marginal people whose daily task of survival does not permit the luxury of more speculative questions. From the edge, the justice or 'injustice' of God is encountered in the way social process operated by man enhances or denies life. The issue of theodicy for Israel is a practice of social criticisms, which do or do not work humanely, and of God who sponsors and guarantees systems that are or are not just. God is known by the system he sanctions through man. Theodicy becomes in fact an irrelevant speculative issue if the God-question is not linked to systems of social access and goods.

For better understanding of this materialist reading Qoheleth in 7:15 openly affirms the uncomfortable fact of injustice in the world because of the social system in operation-"there is a righteous man who perishes in his righteousness, and there is a wicked man who prolongs his life in his evil doing" The two pairs of terms yield a deedconsequence understanding: the righteous perishing and the wicked living long life. The issue is raised by Qoheleth because the consequences contradict each other, which shows that the system of benefit has collapsed. The case is brought before Yahweh because he is the guarantor that certain deeds yield certain consequences, and certain consequences do or do not follow from certain deeds.

The prophets did not philosophize about the causality of evil in relation to a good God. They simply accepted God as the ultimate cause of all things, good and evil (Eliss 1977). The work of God is his government, and his supreme causality is always acknowledged. In Hebrew thought generally, all events are directly in the hands of God, the first cause hence, it can be said that he causes "evil" - without denying man's freedom and responsibility. Qoheleth does not put this fact up as a counter dogma to the optimistic theory of the sages - that good is rewarded and evil is punished-it is simply an ineluctable experience of life. Good things come from God; one must also live with the "evil day" and recognize that it 
comes from God.

The contradiction in deed and consequence is a challenge to God. As conventional discussions of theodicy have recognized, Qoheleth from his wisdom found out that the benefits that should accrue to a righteous man are now those of the wicked who does not merit them. This is a critique of a social system of benefits for which God is at best the invisible guarantor. The accents are much on the social and economic rewards that ought not to be but are, because the system is skewed by man.

Our reading of Qoheleth or any of the theodic literature should depend on our social standpoint. The point is a hermeneutical one. A lively reading which goes hand in glove with a kind of supernaturalism that overlooked all the functions of social process is not in order. But if the text of Qoheleth is read with social realism and we ask how it is that the wicked are well-off, it is because the networks of social process which govern access and power are inclined and arranged that way. The theodicy question addressed to God becomes at the same time skepticism about a social process that is less and less regarded as legitimate. The God of Israel, who is still strongly linked to the revolutionary memories of the Exodus, is never a God apart from social process, but he is the one who is mediated, experienced and practiced in those processes. The destiny of the righteous and the wicked is not simply a heavenly verdict, but a social practice. The verdict of God and the practice of the community hold together, and the discussion is about both, never about one without the other.

\section{The Nigerian Situation}

Adopting this materialist theodic interpretation of Qoheleth to the Nigerian situation, we can observe that there are so many "righteous" men to whom it happens according to the deeds of the wicked, and there are very many wicked men to whom it happens according to the deeds of the righteous. In fact, so many people prolong their lives in their evil doing. Corruption is noticed everywhere while oppression and injustice to the poor masses are no longer news.

Qoheleth's observation that in the place of justice there was wickedness, and in place of righteousness, even there was wickedness, is a serious one in the Nigerian nation. There are many places one would fundamentally expect justicein the family, in the community, private and public institutions etc. In these places leaders, committees and other authorities take decisions on what is to be done or adjudicate cases between people. Specifically and naturally too, one would expect justice also in the Nigerian courts. Courtrooms have "sculptures of lady justice, holding a set of scales" (Darryl 2011). She is often pictured wearing a blindfold to show that she is impartial, and she has a sword in her right hand symbolizing the power of reason and justice that she can wield in the pursuit of truth and fairness, she weighs carefully what is right and what is wrong, and is impartial in her deliberations

But instead of justice, there is injustice in all these expected places of justice, including the law courts. Instead of righteousness, there is wickedness. Ours is a system that rewards mediocre advocacy, bypasses due process and shortchanges both defendants and victims. The public defender pleads most of his clients guilty with scant knowledge about their circumstances; the judge sets outrageous bail for negligible crimes; prosecutor habitually declines to pursue significant cases; they are courts in places of justice that work together to achieve a wrongful conviction. In courts of law proper, ordinary injustice reveals a clubby legal culture of compromise, and shows the tragic consequences that result when communities mistake the rules that lawyers play by for the rule of law.

It is not only injustice that thrives but there is also oppression, tears of the oppressed and power on the side of the oppressors. Oppression is noticed everywhere and it takes the shape of cheating, defrauding, and robbing at the detriment of others; seeking profits without regard to the needs and the rights of other people. Those in power use the power for their own advantage. The powerful abuse their positions and the masses are at the mercy of the oppressors. The justice of God cannot be separated from the actual experience of justice here on earth (Brueggemann, 1985).

The well-being of the oppressors, who are the wicked ones in Nigeria, is not caused directly by God as though by edict, but their well-being takes place through the nexus of socio-political processes. They ride the best cars and build the best houses because the system allows them to dip hand into public purse recklessly to help themselves. They get the best of medical services abroad and their children school overseas, not because they are loved more by God but because they embezzle public money to satisfy their selfish ends at the harm of the masses. Their houses, children and belongings are safe not because some spirits of God watch over them, but because the agents of finance, security and protection are favorably inclined. Security agents and security arms and vehicles meant for the security and protection of the people are deployed for the security and protection of some few individuals and families.

One becomes a president, Governor or local government chairman etc not simply because of God's fair justice through winning in a free and fair election, but because one has behind one "the powerful selecting cabal" and has money needed to buy the most probable "successes" (Ugwueye, 2006). Those who experience physical, material or social well- 
being are those who benefit from the rewards of the system. It is obvious that the blessings and well-being are not given like a bolt from the blue, but are given the way such matters are always administered, through the responsible or irresponsible and reliable or unreliable function of the social system.

Theodicy concerns real power in real social communities. Any critique of God's justice must be a critique of the social agency through which that justice is made concrete. God's governance is through social processes and not without them. Social processes do not displace divine justice but are the means through which it is practised and experienced.

In Nigeria the "wicked" oppressors have come to have monopoly on social goods and access while many others are displaced. Interpreting Qoheleth $5: 8$, Ryder (1982) seemed to have Nigeria in mind when he said that oppression and injustice flourish in a nation, when from top to bottom of its hierarchy of officialdom, each watches the one below him to grasp his pickings of the revenues, the most senior receiving the lion's share. What is shared by a few is what is meant for all.

The discussions dealing on theodicy present a descriptive reflection about the pervasiveness of laws which in their absolute value transcend both the individual God and the unresolved questions of human life. Thus theodicy is not necessarily a vindication of a given god but rather a statement about the ultimate value of the absolute, both in the divine and in human or political sphere (Crenshaw 1983). It is all about how we can eschew evil and injustice in our capacity as human beings created by a just God who has given us a free will to act. Defending God's honor and justice in the face of evil entails, more than anything else, living and acting in a just manner. It entails arranging and operating the social process the way the masses will be benefited.

In contrast to the eighth century prophets, however our conventional handling of theodicy tends to disregard this important understanding of justice and remove the justice question from the arena of social processes to the speculative air of theological reflection. But it should be known that theodicy is a regularly functioning presupposition that permeates every text either as a consensus or a challenge. The entire literature of the Old Testament, since the Exodus narrative, concerns the interface of God and social justice. Social evil such as corruption and injustice are crucial, if not central for theodicy in the Old Testament.

Corruption is responsible in large measure for the broken promises, the dashed hopes and the shattered dreams that have characterized the existence of multitude of Nigerians for some long time now. Both the perpetrators of injustice and oppression and the sufferers of injustice and oppression rush to the defence of God's justice and appeal to him as the legislator of their conditions. The oppressors who are the ruling class - ranging from the presidency, corrupt church leaders to the local government chairman and their cohorts- claim to be enthroned by God and to be doing God's wish.

The oppressed poor masses have two sub-groups. One sub-group says the social situation is its own share of God's justice while the other sub-group is asking God to intervene and abrogate the system for their immediate liberation. Not only that the cost of corruption is telling much on the latter but also that it is very sensitive to the cause of its problem but is powerless to act. In many Nigerian villages and towns, it is common to see many families starving for lack of food to eat while some few are stealing and lavishing what is meant for all. This is injustice, it is social evil. An enquiry into such an arrangement that gives abundant life to some few at the detriment of many others is what our materialist theodic reading is all about.

The Nigerian nation needs to make a settlement concerning how much evil and suffering is necessary, legitimate and bearable. An agreement on the amount of suffering to be borne in situations of unequal power and privilege, in which some are happy while others suffer, is very necessary now. The majority of the sufferers of this social evil can no longer accept the evil and the assignment of such to them by the "wicked" and this gives rise to crisis. The powerless and the despondent fatalists in the two sub-groups of the masses above can do better by seriously questioning and confronting the arrangement and practice of the unjust system.

The odd reality is that a settlement may be long to come, but the crisis is however acute because these theodic questions are already raised. It may or may not lead to a revolution similar to the Islamic awakening witnessed recently in Arab regions. Revolution is not only a seizure of power, but is a change in the rules through which power and access are apportioned.

\section{Conclusion}

Injustice, suffering and oppression are rampant in Qoheleth's world of wisdom, just as we have them in Nigeria. It is enough to make one wonder whether we are any better off than animals, whether it is better off never having lived. It is an unfair world full of injustice and oppression, and it looks like we are powerless to change it. Why doesn't God intervene? Why does God let the bullies of life win?

Inasmuch as resolving the above theodic questions are important, they go hand in hand with why the socio-political 
system and Nigerian leaders and the elite are unjust. Injustice and oppression do not thrive in the air but within a social system operated by beings created by God. The same beings created by God are direct victims of injustice and oppression. Why should this unfair situation be tolerated? How can things be done better to curb the excesses of some and enhance the lives of others? Action is needed to redress this.

Religion does not so much offer solutions to the problem of suffering, but rather provides the promise of a God who is completely present with us in suffering. We can afford to be theoretical about the issues of suffering and oppression from the relative comfort of our lives. But in the middle of the injustice and oppression that Qoheleth writes about, one cannot but think of acting to put things right (Paulipopo 2011). Imagine that you are preaching, delivering a lecture or talking to people in a war zone. Among the listeners are people whose cities and villages have been plundered by Boko Haram dissidents, then burnt and leveled to the ground, whose daughters and sisters have been raped, whose fathers and brothers have had their throats slit. The theme of the sermon, lecture or talk is "a godly man's attitude of non-violence toward violence" and the thrust of the message is that children of God should not retaliate since God is perfect nonviolent love. Soon one would discover that it is difficult if not impossible to accept this theory that human non-violence corresponds to God's refusal to judge. In a scorched land, soaked in the blood of the innocent, such thesis will invariably die.

Reflecting on the above scenario, one remembers many other situations of injustice and violent oppressions in Nigeria where cosmetic approaches failed to stop the tears of the oppressed. As Qoheleth observed, the only thing that qualifies these oppressors to oppress is the power behind them. Those activities involved in getting and using power in public life, and being able to influence decisions that affect a country or a society could be referred to as politics (Hornby, 2000). However, there are other kinds of power-economic and other wise - but political power ranks highest. The power Qoheleth writes about is in itself neutral and perceived through its activity. According to Ogbu (2012) power is akin to the relationship between air and wind. Wind is air in motion. So the legitimate question of power is its activity by the people who hold it and for whom and to what end.

Everyone in Nigeria is involved in deciding this issue of power within one's sphere of work or locality and in Nigeria as a nation especially when one is a victim of injustice. The motive, mission and operation should carry along the truth that God of Qoheleth is in our world of flesh and blood, tears and death, injustice and oppression in other to trigger off justice, liberty and freedom through the actions of men.

\section{Reference}

Brueggemann, W. (1977). Theodicy in social dimension. Journal for the study of Old Testament. 33, 3 -25

Crenshaw J.L. (1983). Introduction: the shift from theodicy to anthropodicy. In J.L.

Crenshaw (Eds.). Theodicy in the Old Testament: issues in religion and Theology 4 (pp.1-16). London: SPCK

Daryl D. (2011). Living and working in an unjust world (Ecclesiastes 3:16 - 4:6). (online) Available: http//www.dashsermons.com/2011 Living-and-world-ecclesiastes-316-46/Dashsermons (March 20,2011)

Ellis P.F. (1977). 1 - 2 Kings. In R.E. Brown (Eds.). The Jerome biblical commentary. (pp.179-209) London \& Dublin: Geoffrey Chapman.

Hicks J. (1985). Evil and the God of love. London: Macmillan

Murphy R.E. (1977). Ecclesiastes (Qoheleth). In R.E. Brown (Eds.). The Jerome biblical Commentary (pp.535-540). London \& Dublin: Geoffrey Chapman.

Ogbu U. K. (2012). The scourge of the vandals. Nature and control of cult in Nigerian University system. Nsukka: Joen Press

Paulipopo (2011). Pentecostal churches in Lagos Nigeria. (online) Available: http//:hubpages.com/hub/Pentecostal-churches-in-LagosNigeria (January 3, 2011)

Ryder E.T. (1982). Ecclesiastes. In M. Black \& H.H. Rowley (Ed). Peake's commentary on the Bible (pp.458-467). Hong Kong: Theommar Nelson \& sons.

Schuuman H. (1996). Theodicy. In B. C. Paul and L. Andrew (Ed.). Dictionary of Ethics, theology and society (pp.816-819). London and New York: Rutledge

Stephenson S.S., Voorhees R.W. \& Morris W. (2004). The new International Webster's Comprehensive dictionary of the English language, encyclopedic edition. Naples Florida: Typhoon international.

Stuhlmueller C. (1977). Post-exilic period: spirit, Apocalyptic. In R.E. Brown (Eds). The Jerome biblical commentary (pp.377-343). London \& Dublin: Geoffrey Chapman.

Ugwueye L.E. (2006). Theodicy in Qoheleth. Unpublished PhD Thesis. University of Nigeria, Nsukka. 